\title{
Geostatistical and geospatial assessment of soil pollution with heavy metals in Pavlograd city (Ukraine)
}

\author{
Mykola M. Kharytonovi,,", Sergey A. Stankevich², Olga V. Titarenko², \\ Helena Doležalová Weisssmannová ${ }^{3}$, Iryna I. Klimkina ${ }^{4}$, Liliya A.Frolova ${ }^{5}$
}

${ }^{1}$ Dnipro State Agrarian and Economic University, Dnipro, Sergey Efremov str., 25, 49600, Ukraine, e-mail: kharytonov.m.m@dsau.dp.ua

*corresponding author's e-mail: kharytonov.m.m@dsau.dp.ua

${ }^{2}$ Scientific Centre for Aerospace Research of the Earth, NAS of Ukraine, Kiev,

O. Gonchar str., 55-b., 01054, Ukraine

${ }^{3}$ University of Technology, Brno, Purkyňova str.115, 61200, Czech Republic

${ }^{4}$ Dnipro University of Technology, Dnipro, Dmytro Yavornytskiy Av. 19, 49005, Ukraine

${ }^{5}$ Ukrainian State University of Chemistry and Technology, Dnipro, Gagarin av. 5, 49008, Ukraine

Received: 29 February 2020 / Accepted: 6 April 2020

\begin{abstract}
This paper presents the result of studies of the geostatistical and geospatial assessment heavy metal pollution in soils caused by various technogenic sources to assess the environmental impact of industrial agglomeration activitiy in the Pavlograd city. The main sources of technogenic pollution in the Pavlograd city and suburban areas are industrial enterprises, coal-fired plants, mine dumps and other. The vast number of analyzed soil samples with weakly acidic $\mathrm{pH}$ values from 6.3 to 6.8 is characterized as loam (63\%), the rest are sand $(33 \%)$ and clay soils $(4 \%)$. The correlation matrix of metals data indicates positive correlation with correlation coefficient $r^{2}>0.5$ among texture $-\mathrm{Ni}(0.705)$ and $\mathrm{Pb}-\mathrm{Zn}(0.695)$ within the Pavlograd city area. In the case of $\mathrm{Cu}(2.73)$ and $\mathrm{Cd}$ (4.27), the geoaccumulation index indicated "moderately to strongly" and "strongly to extremely" polluted soils accordingly. Means of pollution index $(P I)$ for heavy metals were between uncontaminated $(P \leq 1)$ and of moderate contaminated soils $(P \geq 1)$. The results of this study show that industrial enterprises' activities lead to heavy metal contamination in the topsoil of the studied sites and close to the background values. Similar properties were confirmed by principal component analysis (PCA) and cluster analysis. The PCA and cluster analysis results indicate that $\mathrm{Cd}, \mathrm{Ni}, \mathrm{Pb}, \mathrm{Cu}, \mathrm{Zn}$ and $\mathrm{Mn}$ in topsoil were affected by the technogenic activity. The spatial distribution characteristics of $\mathrm{Cu}, \mathrm{Pb}, \mathrm{Cd}$ and $\mathrm{Zn}$ in the geochemical maps are also similar. Highlighted are some of the halos in Pavlograd of high density of total soil contamination with heavy metals. The metals come from anthropogenic sources, mainly produced with four industrial enterprises in Pavlograd city. Mostly they are concentrated in the Southeast and West of the city and suburban areas of the Pavlograd district. Therefore, it is necessary arrangements to predict of the development of ecologically dangerous state of environmental pollution within the area of industrial enterprises of city.
\end{abstract}

Keywords: Environmental state, technogenic pollution, soil, heavy metals.

\section{Introduction}

The social, logistic, medical, urban heat and air quality consequences of urbanization and large industrial cities' development create numerous problems (Karnaukh \& Lugovskoy, 2008; Crutzen, 2004). The air basin of industrial agglomerations is extremely polluted in spite of the permanent convection and inter-boundary transfer (Parrish et al., 2011; Dufour et al., 2004).

High level of air pollution is connected with various economic activities. As a result, the air quality is very low. The large number of industrial enterprises in the Dnieper 
natural-economic region leads to the formation of technogenic anomalies of atmosphere pollution (Babiy et al., 2003). Consequently, the inhabitants adjacent to industrial enterprises, as well as residential areas are "hostages" of a certain number of mining and metallurgical industry, fuel-energy complex and patterns of functioning vehicles (Masaitis \& Miller, 2014; Ghorani - Azam et al., 2016). The level and character of airborne soil pollution depend on different reasons: quantity and quality of industrial and traffic emissions, type and intensity of physical and chemical atmospheric processes, land surface etc (Maas et al., 2010; Joshi \& Balasubramanian, 2010; Johansson et al., 2009). The main reasons, which determine the air quality, are volume and composition of industrial emissions (Biliaiev et al., 2017).

The main pollution sources in the southeastern part of Ukraine are facilities of metallurgy, power industry, mining and petrochemical industries. One of the most polluting industries in Pre-Dnieper region is the ferrous and nonferrous metallurgical production plants. The steel industry originally developed because of plentiful and high quality local resources of iron and coal in Krivbass and Western Donbass mining regions. The majority of the sector is related to steel production. Structural issues, poor energy efficiency and environmental problems are intertwined in this industry (Voitiuk et al., 2014).

General maintenance and housekeeping are poor. The technologies used in much of the industry are outdated and energy inefficient. Last decade there are modern sections founded in some plants built in Dnipro city (e. g. InterPipe metallurgical plant).

The chemical industry is more diverse in terms of production and its process technologies, on average, are not as old as those used in the steel industry (Babiy et al., 2003). The large number of industrial enterprises of Western Donbass coal mining region leads to the formation of technogenic anomalies of atmosphere pollution caused with dust emissions of coal-fired heat-and-power objects (Kolesnik et al., 2018). The coal and mine rocks contain significant amounts of heavy metals and rare-earth elements. Settling on the land's surface, they form insoluble compounds and accumulate in the upper parts of the soil cover.

The study objective is environmental assessment of soil technogenic pollution in the area of industrial enterprises within the Pavlograd city area.

\section{Materials and methods}

The Pavlograd city is located between Samara and Vovcha rivers. The investigated area belongs to the North-East slope of the Ukrainian crystalline massif and extends along the South-Western side of the Dnieper-Donets basin. From the South to the North of the city crossed with Vovcha river (over $2.85 \mathrm{~km}$ ). Samara river is a natural boundary from the North-East. Two small rivers entitled as "Gnyzdka" $(3.9 \mathrm{~km})$ and "Kocherga" $(2.9 \mathrm{~km})$ cross the territory of the city of Pavlograd as well. The most common soils are typical black and meadow soils. Underground fresh and mineral water are essential to the life of the city.

The climate is the Atlantic-continental, not humid, characterized by hot summers, with the thaw, dry. The average temperature for the year is $4.4^{\circ} \mathrm{C}$. The Number of dry days is approx. 80 (April-October). The priority direction of the wind: during the warm season - West $(18 \%$ of the days); during the coldest season - East ( $23 \%$ of days). Forest area both around and within the city are presented with large tracts of pine trees. Investment potential of the city is characterized, in particular, for existing production facilities relating to various forms of ownership. More than one thousand real estate objects belong to communal property of the city territorial community. The numerous sources of soil pollution in Pavlograd city and suburban territories are four industrial enterprises, mine tailings, heat supply companies and transport. There are 32 industrial enterprises with more than 600 organized sources and emit more than 1,000 tons of pollutants (including more than 350 tons of carbon monoxide, 130 tons of oxides of nitrogen, 280 tons of suspended solids) in the Western Donbass region. Main industrial emission sources of air pollution in Pavlograd city are following: Pavlograd chemical plant (PCP), Pavlograd mechanical plant (PMP), Pavlograd machine factory (PMF) and Pavlograd foundry plant (PFP). Soil samples were taken to determine the effect of airborne technogenic pollution in Pavlograd (Fig. 1). Soil samples were collected in the vicinity of each enterprise to detail the impact of the main environmental pollutants in Pavlograd city. Soil sampling was performed by the method of "envelope". The total number of samples is 60 . The soil samples were collected in the depth $0-10 \mathrm{~cm}$, mass of each sample was 800-900 g. After that, soil samples were dried at room temperature and powdered, have been removed impurities and particles using sieves with holes of different diameter from 5 to $1 \mathrm{~mm}$. The shredded material is thoroughly mixed and scattered smooth a thin layer in the form of a square, was divided into four sectors to reduce the mass of the sample. The content of the two opposite sectors was discarded, and the remaining two were again mixed.

After multiple repetitions, the sample remained was dried to obtain extracts from the soil. The definition of the content of acid-soluble forms of heavy metals in the collected samples was performed using atomic absorption spectrophotometry method. Assessment of soils ecological quality was given by the degree of soil contamination with HM regarding exceeding the maximum permissible concentrations (MPC) of pollutants established by Ukrainian legislation (Fedoniuk et al., 2020). In order to assess heavy metal contamination of soils the following pollution 


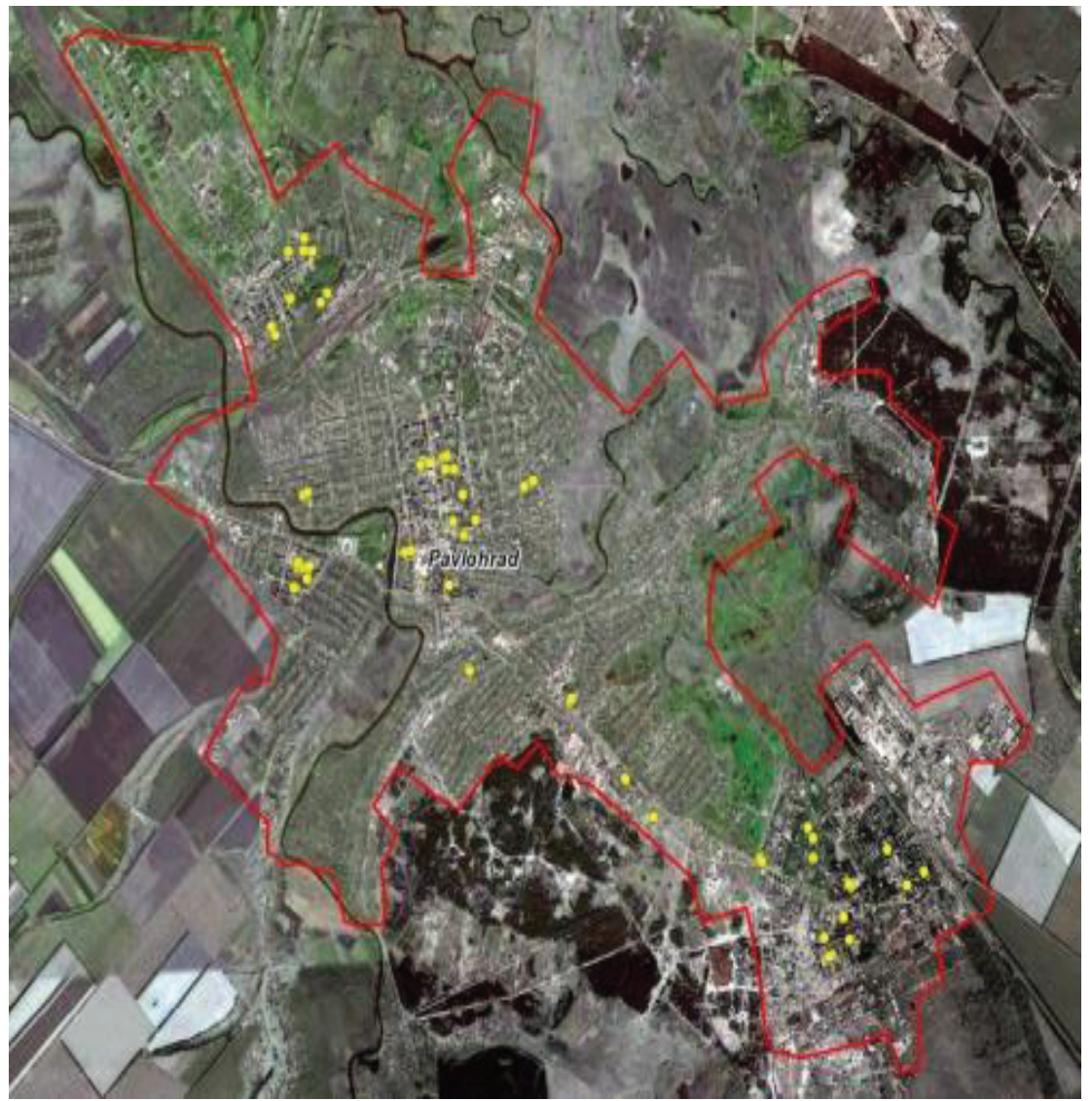

Figure 1. Soil sampling locations

three indices were calculated. Geoaccumulation index $\left(I_{g e o}\right)$ enables the estimation of pollution by comparing current and preindustrial concentrations (Müller, 1969; Khalilova \& Mammadov, 2016).

$$
I_{\text {geo }}=\log \left(\frac{C_{n}}{1.5 B_{n}}\right)
$$

where $C_{n}$ is the measured concentration of the element in soil; $B_{n}$ is the value of background concentration (BC) of element $n$, and 1.5 is the background matrix correction factor due to lithogenic effects (the constant 1.5 is introduced to minimize the effects of possible variations in the background values that may be attributed to lithologic variations in soils). The $I_{\text {geo }}$ was classified into six categories: $I_{\text {geo }}<0$ (practically unpolluted, $I_{\text {geo }}=0$ ), $0<I_{\text {geo }}<1$ (unpolluted to moderately polluted, $\stackrel{\text { geo }}{\text { geo }}_{1}=1$ ), $1<I_{\text {geo }}<2$ (moderately polluted, $I_{\text {geo }}=2$ ), $2<I_{\text {geo }}<3$ (moderately to strongly polluted, $I_{\text {geo }}=3$ ), $3<$ Igeo $<4$ (strongly polluted, $I_{\text {geo }}=4$ ), $4<I_{\text {geo }}<5$ (strongly to extremely polluted, $I_{g e o}=5$ ) and $I_{g e o}>5$ (extremely polluted,
$\left.I_{\text {geo }}=6\right)$. The PI of each heavy metal $\left(P I_{i}\right)$ was evaluated with pollution index according to the method of (Lee et al., 1998), calculated as the ratio between the metal concentration $\left(C_{i}\right)$ in sample and maximum permissible concentration (MPC). Maximum permissible concentrations (MPC) of pollutants were established by Ukrainian legislation as reference value-national criteria of the metal and were taken as $S_{i}$ values. It was expressed as stated below:

$P I=\frac{C_{i}}{S_{i}}$

Classification of PI values for each HM contaminated soil was characterized on the basis of criteria such as practically uncontaminated soils $(P \leq 1)$, moderate contaminated soil $(1<P \leq 3)$ or high contaminated soil $(P>3)$. Assessment of soils ecological quality was given by the degree of soil contamination with HM regarding exceeding the MPC. The descriptive statistical analyses were performed using Microsoft Excel spreadsheet and Statistica software by TIBCO Inc. The multidimensional statistical 
methods were applied for the analysis of the environment pollution state within the selected contamination sources of emission: method of PCA and cluster analysis. Satellite radar interferometry (InSAR) digital elevation model (DEM) was used to build a map of terrain elevation changes map in Pavlograd city. Density map of the total soil contamination with copper, zinc, manganese, cadmium, lead and nickel has been created using the 3D Analyst program module of ArcGIS software package by ESRI Corp.

\section{Results and discussion}

Elevation map were acquired to extract the features of the terrain during three years from 2015.11 to 2017.05 using Sentinel 1A satellite InSAR data product.

Terrain elevation maps was acquired using the satellite InSAR based on the two pairs of Sentinel-1A images for the November 2015 to May 2017 time spans. The terrain elevation dynamics for this period of the study area are described by data of Table 1 .

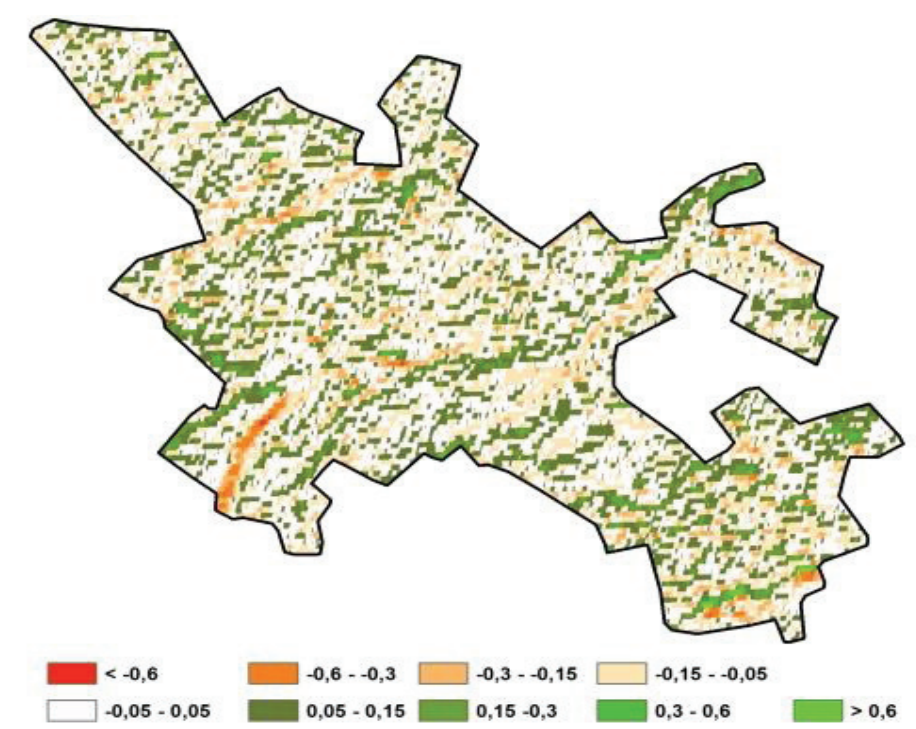

Figure 2. Terrain elevation changes map within the Pavlograd city area

Table 1. Terrain elevation changes in Pavlograd city

\begin{tabular}{|c|c|c|c|c|}
\hline \multirow{2}{*}{ Code } & Color & Class & Difference & Percent \\
\hline \hline 0 & & Unclassified & no data & 0.000 \\
\hline 1 & & Very Strong Down & $<-0.6$ & 0.676 \\
\hline 2 & Strong Down & $-0.6 . .-0.3$ & 3.107 \\
\hline 3 & Moderate Down & $-0.3 \ldots-0.15$ & 8.970 \\
\hline \hline 4 & Weak Down & $-0.15 . .-0.05$ & 17.900 \\
\hline \hline 5 & No Change & $-0.05 . .0 .05$ & 34.127 \\
\hline \hline 7 & Low Rise & $0.05 . .0 .15$ & 22.785 \\
\hline \hline 9 & Medium Rise & 0.3 & 10.132 \\
\hline \hline
\end{tabular}


The relationships among metals concentrations are important information on hazardous metal resources and their pathways in the environment (Johansson et al., 2009; Manta et al., 2002). The details of the correlations matrix are presented in Table 2. The correlation matrix of metals data indicates positive correlation with correlation coefficient $r^{2}>0.5$ among texture $-\mathrm{Ni}(0.705)$ and $\mathrm{Pb}-\mathrm{Zn}$ (0.695) in Pavlograd city. The results metals contaminations of soils within the Pavlograd city were verified and exactly evaluated with the Geoaccumulation index $\left(I_{\text {geo }}\right)$ and PI. Geoaccumulation index $\left(I_{\text {geo }}\right)$ for heavy metals ranged from unpolluted to strongly polluted soil quality (Fig. 3 and Table 3). Soils were moderately polluted by $\mathrm{Pb}$ (1.32), Mn (1.37), Ni (1.44), Zn (1.96) based on geoaccumulation index. In the case of $\mathrm{Cu}$ (2.73) and $\mathrm{Cd}$ (4.27), the geoaccumulation index indicated "moderately to strongly" and "strongly to extremely" polluted soils accordingly. The details of the metal $I_{\text {geo }}$ correlations matrix are presented in Table 4.

Table 2. The correlation coefficient matrix between metals in soil samples (significance level $\alpha=0.05, \mathrm{p}<0.001$ )

Color map of correlations (data in Pavlograd), $\mathrm{N}=60$;

\begin{tabular}{|c|c|c|c|c|c|c|c|c|}
\hline \multirow[t]{2}{*}{ Variable } & \multicolumn{8}{|c|}{ (Case wise deletion of missing data) } \\
\hline & pH & texture & $\mathrm{Cd}$ & Mn & $\mathrm{Cu}$ & $\mathbf{N i}$ & $\mathbf{P b}$ & $\mathbf{Z n}$ \\
\hline $\mathrm{pH}$ & 1.000 & -0.064 & 0.300 & 0.118 & -0.009 & 0.037 & 0.291 & 0.201 \\
\hline texture & -0.064 & 1.000 & -0.117 & -0.011 & 0.139 & 0.705 & 0.056 & -0.012 \\
\hline $\mathrm{Cd}$ & 0.300 & -0.117 & 1.000 & 0.170 & 0.056 & -0.124 & 0.308 & 0.215 \\
\hline $\mathrm{Mn}$ & 0.118 & -0.011 & 0.170 & 1.000 & 0.038 & -0.021 & -0.028 & -0.002 \\
\hline $\mathrm{Cu}$ & -0.009 & 0.139 & 0.056 & 0.038 & 1.000 & 0.178 & 0.221 & 0.254 \\
\hline $\mathrm{Ni}$ & 0.037 & 0.705 & -0.124 & -0.021 & 0.178 & 1.000 & 0.289 & 0.171 \\
\hline $\mathrm{Pb}$ & 0.291 & 0.056 & 0.308 & -0.028 & 0.221 & 0.289 & 1.000 & 0.695 \\
\hline $\mathrm{Zn}$ & 0.201 & -0.012 & 0.215 & -0.002 & 0.254 & 0.171 & 0.695 & 1.000 \\
\hline
\end{tabular}

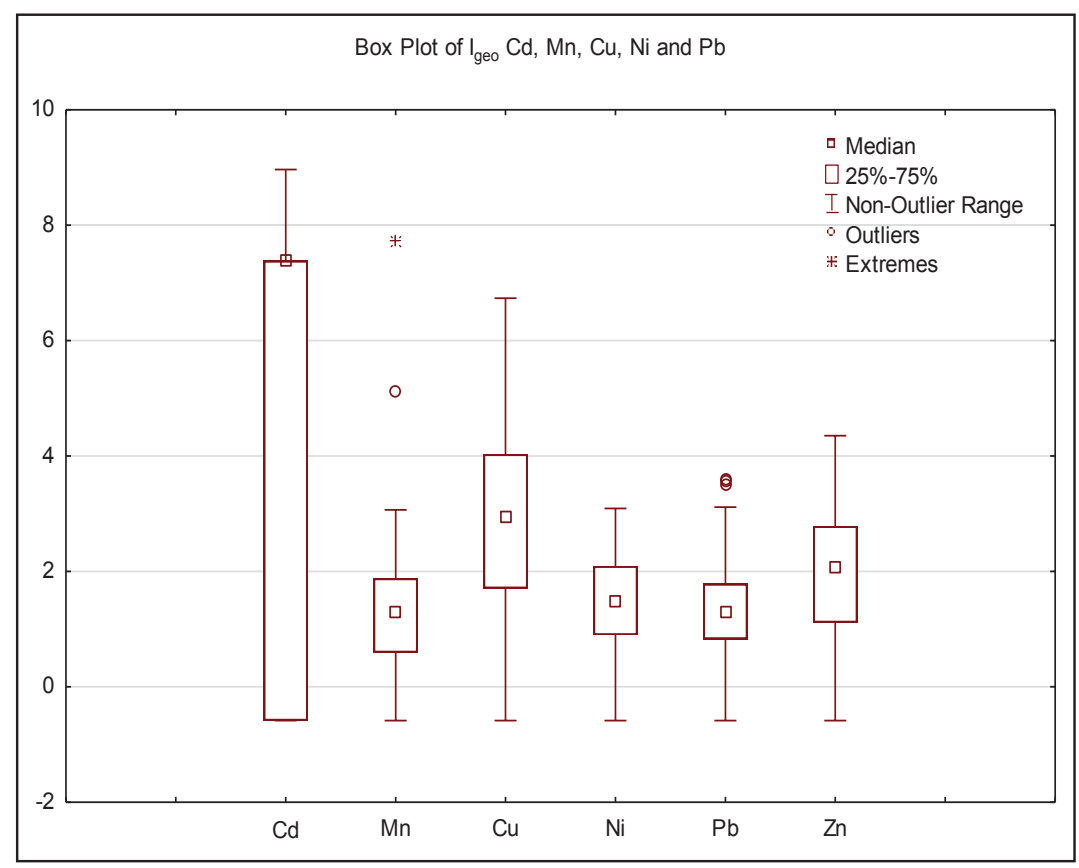

Figure 3. Means of $I_{\text {geo }}$ for heavy metals 
The each parameter correlation matrix data indicate positive correlation with correlation coefficient $r^{2}>0.5$ among texture $-\mathrm{Ni}(0.72)$ and $\mathrm{Pb}-\mathrm{Zn}(0.65)$ in region of Pavlograd.
It was fixed also closed to 0.5 interval correlation coefficient $r^{2}>0.45$ among $\mathrm{Mn}-\mathrm{Pb}(0.45), \mathrm{Cu}-$ $\mathrm{Ni}(0.45)$ and $\mathrm{Cu}-\mathrm{Ni}(0.46)$. Mean of PI increases in the following order $0.2(\mathrm{Cd}), 0.28(\mathrm{Ni}), 0.33(\mathrm{Cu})$,

Table 3. $I_{\text {geo }}$ values

$\begin{array}{ccccccccc}\text { Variable } & \text { Valid N } & \text { Mean } & \text { Median } & \text { Min. } & \text { Max. } & \text { Lower } & \text { Upper } & \text { Std.Dev. } \\ \mathrm{pH} & 60 & 6.530 & 6.500 & 5.800 & 7.000 & 6.500 & 6.600 & 0.167 \\ \text { texture } & 60 & 2.567 & 3.000 & 1.000 & 5.000 & 1.000 & 4.000 & 1.307 \\ \mathrm{Cd} & 60 & 4.272 & 7.381 & -0.585 & 8.966 & -0.585 & 7.381 & 4.158 \\ \mathrm{Mn} & 60 & 1.371 & 1.293 & -0.585 & 7.727 & 0.595 & 1.880 & 1.306 \\ \mathrm{Cu} & 60 & 2.732 & 2.937 & -0.585 & 6.737 & 1.708 & 4.030 & 1.763 \\ \mathrm{Ni} & 60 & 1.439 & 1.485 & -0.585 & 3.093 & 0.900 & 2.093 & 0.830 \\ \mathrm{~Pb} & 60 & 1.319 & 1.290 & -0.585 & 3.611 & 0.830 & 1.784 & 0.998 \\ \mathrm{Zn} & 60 & 1.959 & 2.078 & -0.585 & 4.354 & 1.115 & 2.784 & 1.146\end{array}$

Table 4. The correlation coefficient matrix between $\mathrm{pH}$, texture and $I_{\text {geo }}$ for heavy metals

\begin{tabular}{|c|c|c|c|c|c|c|c|c|}
\hline \multirow{2}{*}{ Variable } & \multicolumn{8}{|c|}{ Color map of correlations } \\
\hline & pH & texture & Cd & Mn & $\mathbf{C u}$ & $\mathbf{N i}$ & $\mathbf{P b}$ & $\mathbf{Z n}$ \\
\hline $\mathrm{pH}$ & 1.000 & -0.064 & 0.252 & 0.133 & 0.119 & 0.054 & 0.227 & 0.156 \\
\hline texture & -0.064 & 1.000 & -0.125 & 0.379 & 0.394 & 0.720 & 0.206 & 0.037 \\
\hline $\mathrm{Cd}$ & 0.252 & -0.125 & 1.000 & -0.030 & 0.024 & -0.022 & 0.076 & 0.162 \\
\hline $\mathrm{Mn}$ & 0.133 & 0.379 & -0.030 & 1.000 & 0.401 & 0.452 & 0.182 & 0.099 \\
\hline $\mathrm{Cu}$ & 0.119 & 0.394 & 0.024 & 0.401 & 1.000 & 0.452 & 0.450 & 0.330 \\
\hline $\mathrm{Ni}$ & 0.054 & 0.720 & -0.022 & 0.452 & 0.452 & 1.000 & 0.463 & 0.361 \\
\hline $\mathrm{Pb}$ & 0.227 & 0.206 & 0.076 & 0.182 & 0.450 & 0.463 & 1.000 & 0.645 \\
\hline $\mathrm{Zn}$ & 0.156 & 0.037 & 0.162 & 0.099 & 0.330 & 0.361 & 0.645 & 1.000 \\
\hline
\end{tabular}

Table 5. PI index for heavy metals

$\begin{array}{ccccccccc}\text { HM } & \text { Valid N } & \text { Mean } & \text { Median } & \text { Minimum } & \text { Maximum } & \text { Lower } & \text { Upper } & \text { Std.Dev. } \\ \mathrm{Cd} & 60 & 0.200 & 0.250 & 0.001 & 0.750 & 0.001 & 0.250 & 0.199 \\ \mathrm{Mn} & 60 & 0.965 & 0.351 & 0.095 & 30.287 & 0.216 & 0.526 & 3.901 \\ \mathrm{Cu} & 60 & 0.334 & 0.209 & 0.018 & 2.909 & 0.091 & 0.446 & 0.430 \\ \mathrm{Ni} & 60 & 0.279 & 0.247 & 0.059 & 0.753 & 0.165 & 0.376 & 0.152 \\ \mathrm{~Pb} & 60 & 0.451 & 0.344 & 0.094 & 1.719 & 0.250 & 0.485 & 0.370 \\ \mathrm{Zn} & 60 & 0.413 & 0.331 & 0.052 & 1.600 & 0.170 & 0.540 & 0.346\end{array}$


$0.41(\mathrm{Zn}), 0.45(\mathrm{~Pb})$, and $0.96(\mathrm{Mn})$, as shown in Table 5 and Figure 4.

The reason of this contamination is fact that industrial works emissions and traffic emission are the different in Pavlograd city and district. Maximum PI values were constant for manganese (30.3) and copper (2.9). The details of the metal PI correlations matrix are presented in Table 6.

The correlation matrix data indicate positive correlation with correlation coefficient $r^{2}>0.5$ among texture $-\mathrm{Ni}$ (0.7) and $\mathrm{Pb}-\mathrm{Zn}(0.695)$ in city. PCA outputs are described by the Table 7 .
The first two principal components of the Table 7 determine the $54.74 \%$ of total contribution into covariance matrix.

The projection of metals concentration's distribution onto principal components plane is shown in Fig. 5.

The projections of the distribution of $\mathrm{pH}$, texture, metals $I_{g e o}$ and PI on the principal components plane are shown in Figure 6

The PCA was used to identify the sources of contamination (Fachinelli et al., 2001). All of the elements are consequently well represented by these two principal compo-

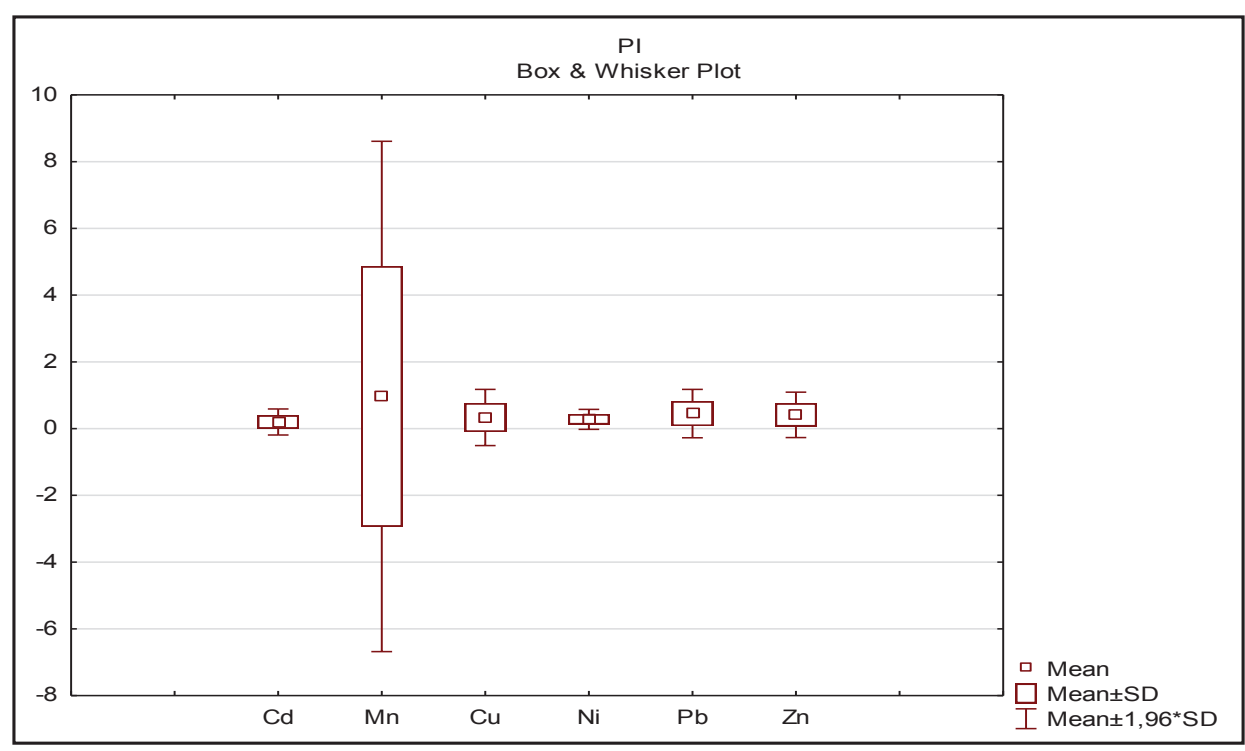

Figure 4. Means of PI for heavy metals

Table 6. The correlation coefficient matrix between $\mathrm{pH}$, texture and PI for heavy metals

\begin{tabular}{cccccccccc} 
Variable & $\mathbf{p H}$ & texture & $\mathbf{C d}$ & $\mathbf{M n}$ & $\mathbf{C u}$ & $\mathbf{N i}$ & $\mathbf{P b}$ & $\mathbf{Z n}$ \\
\hline $\mathrm{pH}$ & 1.000 & -0.067 & 0.300 & 0.118 & -0.009 & 0.038 & 0.291 & 0.201 \\
texture & -0.067 & 1.000 & -0.117 & -0.011 & 0.139 & 0.705 & 0.056 & -0.012 \\
$\mathrm{Cd}$ & 0.300 & -0.117 & 1.000 & 0.170 & 0.056 & -0.124 & 0.309 & 0.216 \\
$\mathrm{Mn}$ & 0.118 & -0.011 & 0.170 & 1.000 & 0.038 & -0.021 & -0.028 & -0.002 \\
$\mathrm{Cu}$ & -0.009 & 0.139 & 0.056 & 0,038 & 1,000 & 0,178 & 0.221 & 0.254 \\
$\mathrm{Ni}$ & 0.038 & 0.705 & -0.124 & -0.021 & 0.178 & 1.000 & 0.290 & 0.171 \\
$\mathrm{~Pb}$ & 0.291 & 0.056 & 0.309 & -0.028 & 0.221 & 0.290 & 1.000 & 0.695 \\
$\mathrm{Zn}$ & 0.201 & -0.012 & 0.216 & -0.002 & 0.254 & 0.171 & 0.695 & 1.000 \\
\hline
\end{tabular}


Table 7. Total variance of explained and component matrices

\begin{tabular}{|c|c|c|c|c|c|c|}
\hline \multirow{2}{*}{ Variable } & \multicolumn{4}{|c|}{ Factor coordinates $(\mathrm{PC})$ of the variables } & \multicolumn{2}{|c|}{ Eigen values of matrix } \\
\hline & PC 1 & PC 2 & PC 3 & PC 4 & Eigen value & Total, \% \\
\hline $\mathrm{Cd}$ & -0.413 & -0.718 & 0.159 & 0.035 & 2.060 & 34.328 \\
\hline $\mathrm{Mn}$ & -0.051 & -0.567 & -0.739 & -0.265 & 1.225 & 20.409 \\
\hline $\mathrm{Cu}$ & -0.478 & 0.187 & -0.448 & 0.727 & 0.984 & 16.404 \\
\hline $\mathrm{Ni}$ & -0.408 & 0.594 & -0.369 & -0.440 & 0.821 & 13.681 \\
\hline $\mathrm{Pb}$ & -0.883 & 0.003 & 0.198 & -0.160 & 0.636 & 10.603 \\
\hline $\mathrm{Zn}$ & -0.843 & -0.010 & 0.191 & -0.032 & 0.275 & 4.575 \\
\hline$* \mathrm{pH}$ & -0.275 & -0.215 & 0.047 & -0.118 & & \\
\hline *texture & -0.167 & 0.437 & -0.329 & -0.267 & & \\
\hline
\end{tabular}

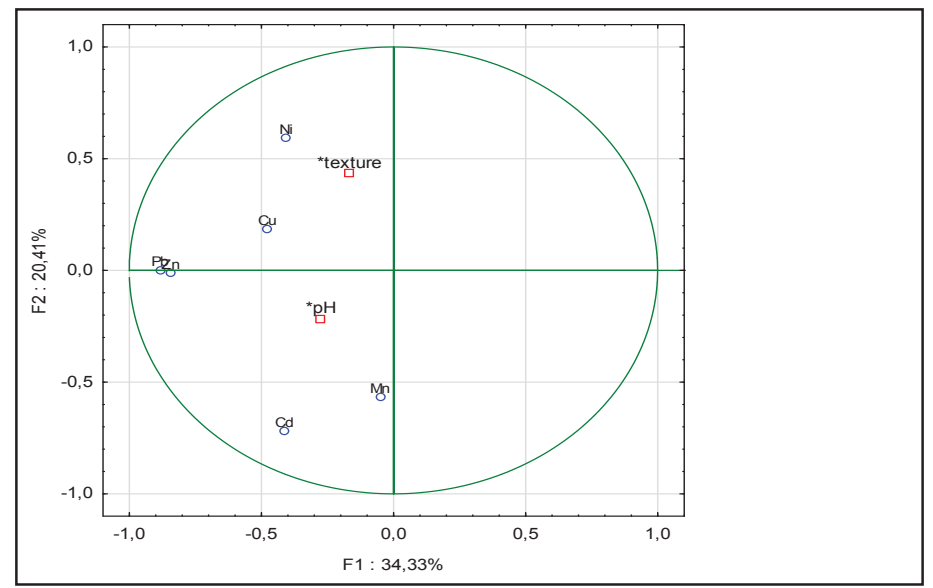

Figure 5. The first two principal components distribution
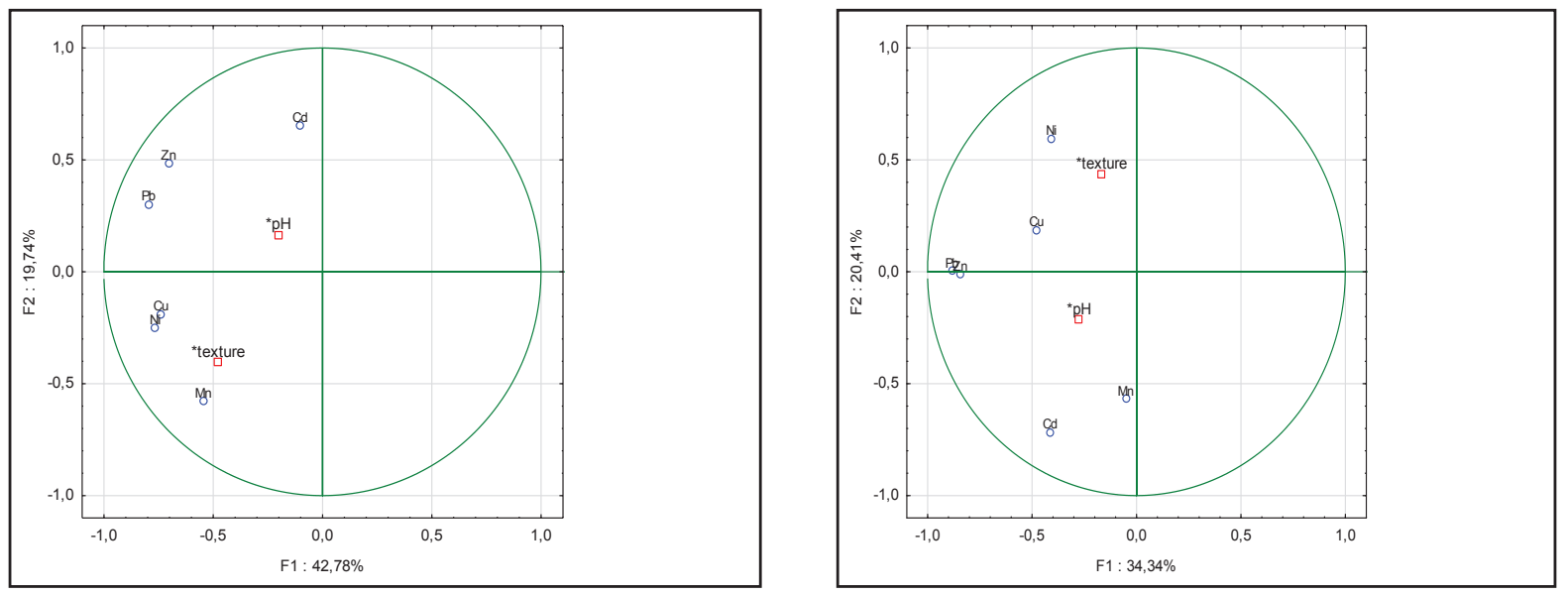

Figure 6. The principal component analysis for $I_{\text {geo }}$ (left) and PI (right) indices 
nents. Total variances explained by first two principal components are in Tables 8 and 9.

The first two principal components of the Table 8 determine the $62.5 \%$ of total contribution into covariance matrix. First PC is in negative relation with correlation coefficient $r^{2}>0.5$ for $\mathrm{Cu}(-0.738), \mathrm{Ni}(-0.766), \mathrm{Pb}(-0.796)$. Second $\mathrm{PC}$ is in positive relation with $\mathrm{Cd}(0.651)$ and negative relation with $\mathrm{Mn}(-0.578)$. Next two principal components determine the $24.3 \%$ of total variance contribution. Third PC is in negative relation with correlation coefficient $r^{2}>0.5$ for $\mathrm{Cd}(-0.747)$. Fourth $\mathrm{PC}$ is in negative relation with $\mathrm{Cu}(-0.622)$ and $\mathrm{Mn}(-0.578)$. The first two principal components of the Table 9 determine the $54.75 \%$ of total contribution into covariance matrix. First PC is in negative relation with $\mathrm{Pb}(-0.883)$ and $\mathrm{Zn}(-0.843)$. Second and third PCs are in negative relation with $\mathrm{Cd}(-0.717)$ and $\mathrm{Mn}$ $(-0.738)$. Fourth $\mathrm{PC}$ is in positive relation with $\mathrm{Cu}(0.727)$.
Thus the metals in the PC $1-4$ probably come from anthropogenic sources, mainly produced with four industrial enterprises in Pavlograd city. 3D surfaces and contour plot of $\mathrm{Cd}, \mathrm{Mn}, \mathrm{Cu}, \mathrm{Ni}$ and $\mathrm{Pb}$ against $\mathrm{pH}$ and texture were built to show and to analyze corresponding distributions (Figs. 7 and 8).

Cluster analysis was performed to divide the clusters of $\mathrm{pH}$, texture and 6 heavy metals and to analyze possible sources within the Pavlograd city area (Fig. 9). Ward method was chosen to determine the Euclidean distance as the most common technique applied for the distance metric. The cophenetic correlation coefficient (CC) was applied to verify the results obtained. The $\mathrm{pH}$, texture and $\mathrm{Cd}$ are forming one independent cluster. $\mathrm{Cd}$ is mainly from the mining and smelting of non-ferrous metals. It is known that coal combustion is also important source of cadmium (Guan et al., 2014).

Table 8. Total variance of explained and component matrices for heavy metals $I_{g e o}$

$\begin{array}{ccccccc}\text { Variable } & \text { PC 1 } & \text { PC 2 } & \text { PC 3 } & \text { PC 4 } & \text { Eigen value } & \text { Total, \% } \\ \mathrm{Cd} & -0.102 & 0.651 & -0.747 & 0.016 & 2.567 & 42.783 \\ \mathrm{Mn} & -0.545 & -0.578 & -0.425 & 0.173 & 1.184 & 19.735 \\ \mathrm{Cu} & -0.738 & -0.189 & -0.103 & -0.622 & 0.900 & 14.995 \\ \mathrm{Ni} & -0.766 & -0.252 & -0.034 & 0.357 & 0.561 & 9.344 \\ \mathrm{~Pb} & -0.796 & 0.301 & 0.284 & 0.003 & 0.458 & 7.632 \\ \mathrm{Zn} & -0.704 & 0.485 & 0.261 & 0.125 & 0.331 & 5.511 \\ * \mathrm{pH} & -0.202 & 0.165 & -0.171 & -0.014 & & \\ * \text { texture } & -0.477 & -0.403 & -0.072 & 0.142 & \end{array}$

Table 9. Total variance of explained and component matrices for heavy metals PI

$\begin{array}{ccccccc} & \text { PC 1 } & \text { PC 2 } & \text { PC 3 } & \text { PC 4 } & \text { Eigen value } & \text { Total, \% } \\ \mathrm{Cd} & -0.414 & -0.717 & 0.160 & 0.034 & 2.060 & 34.337 \\ \mathrm{Mn} & -0.051 & -0.568 & -0.738 & -0.265 & 1.225 & 20.411 \\ \mathrm{Cu} & -0.478 & 0.187 & -0.449 & 0.727 & 0.984 & 16.396 \\ \mathrm{Ni} & -0.408 & 0.594 & -0.369 & -0.441 & 0.821 & 13.684 \\ \mathrm{~Pb} & -0.883 & 0.003 & 0.198 & -0.160 & 0.636 & 10.600 \\ \mathrm{Zn} & -0.843 & -0.010 & 0.191 & -0.031 & 0.274 & 4.572 \\ * \mathrm{pH} & -0.276 & -0.215 & 0.048 & -0.118 & & \\ * \text { * texture } & -0.167 & 0.437 & -0.330 & -0.268 & \end{array}$


$\mathrm{The} \mathrm{Pb}, \mathrm{Ni}$ and $\mathrm{Cu}$ are of similar characteristics and are forming one cluster. $\mathrm{As}$ usual $\mathrm{Pb}$ and $\mathrm{Cu}$ associated with traffic, combustion, waste incinerators, pipes, cables, paints, and colors (Biasioli et al., 2006; Van Bohemen \& Janssen van de Laak, 2003). Both clusters are associated with $\mathrm{Zn}$. The last cluster includes Mn only. Two clusters analysis for $\mathrm{pH}$, texture, $I_{g e o}$ and PI for heavy metals were made for comparative assessment of Euclidean distances (Fig.10).

Cluster of Figure 10 were used to classify all contamination parameters. The smaller the value on the distance cluster, the more significant the association (Luo et al.,
2007). pH, texture indices and 6 heavy metals, were classified and merged into three distinct clusters in the Figure $10 a$. The first cluster include $\mathrm{Zn}, \mathrm{Pb}$ and $\mathrm{Ni}$ are most likely associated with $\mathrm{Mn}$. The second cluster included $\mathrm{Cu}$ and texture and the third one included $\mathrm{pH}$ and $\mathrm{Cd}$. Accordingly to the Figure $10 \mathrm{~b} \mathrm{Zn}$ and $\mathrm{Pb}$ are in the first cluster. These two elements are in positive relation with $r^{2}=0.695$ (Table 5). Cd, $\mathrm{Ni}$ and $\mathrm{Cu}$ are in the second cluster. Both clusters are highly likely associated with texture. $\mathrm{pH}$ and $\mathrm{Mn}$ are last vertexes of this dendrogram. Soil texture distribution map is shown in Figure 11.

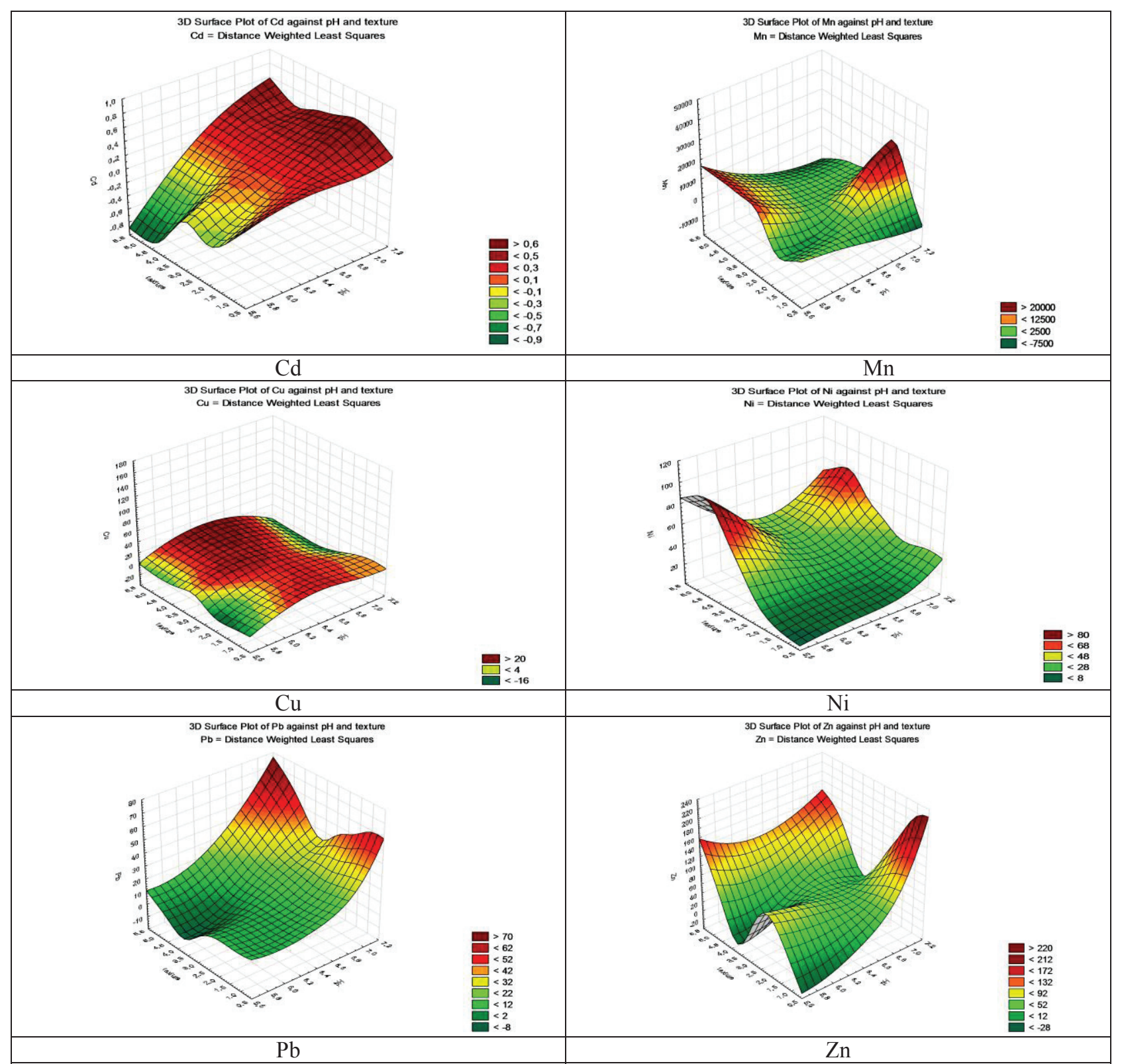

Figure 7. 3D surfaces of $\mathrm{Cd}, \mathrm{Mn}, \mathrm{Cu}, \mathrm{Ni}$ and $\mathrm{Pb}$ against $\mathrm{pH}$ and texture 


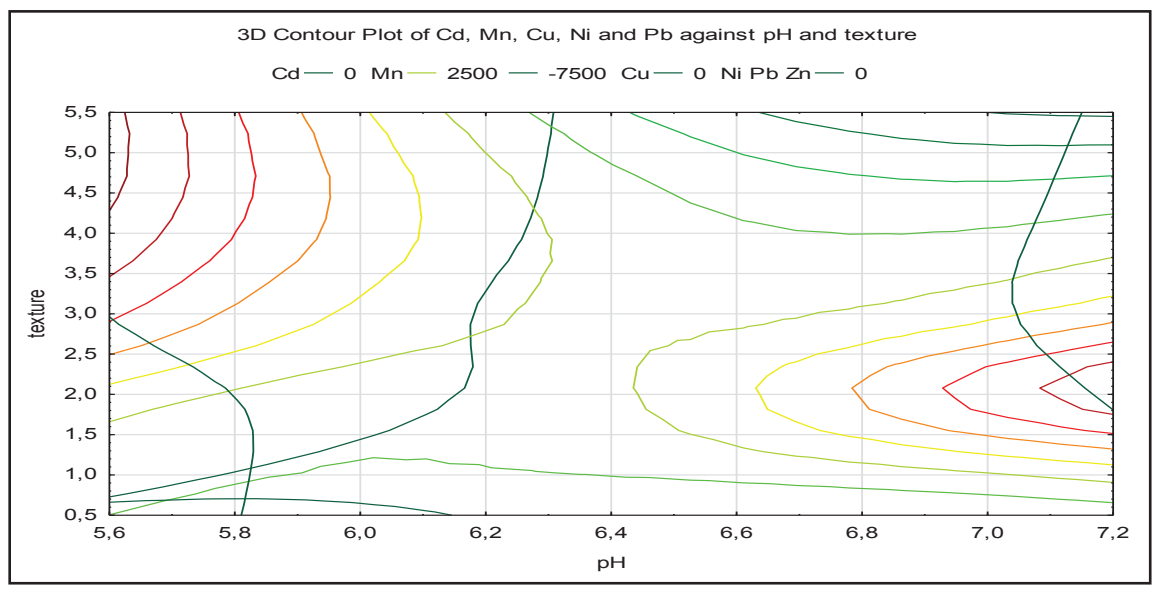

Figure 8. The contour plot of $\mathrm{Cd}, \mathrm{Mn}, \mathrm{Cu}, \mathrm{Ni}$ and $\mathrm{Pb}$ against $\mathrm{pH}$ and texture

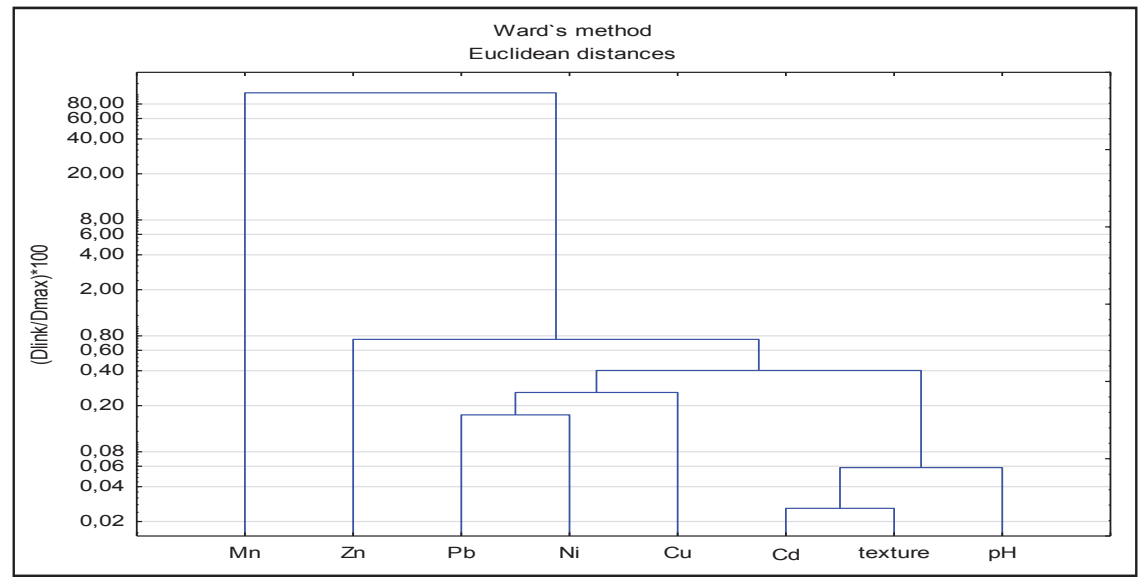

Figure 9. Clusters' dendrogram of 8 contamination parameters

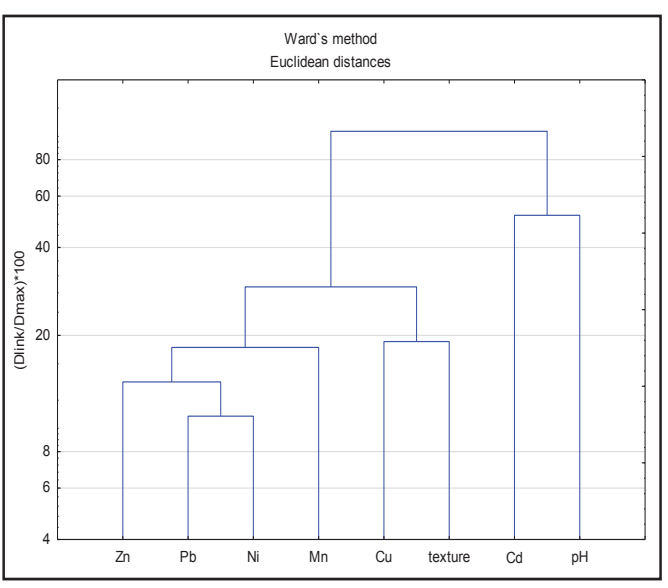

a)

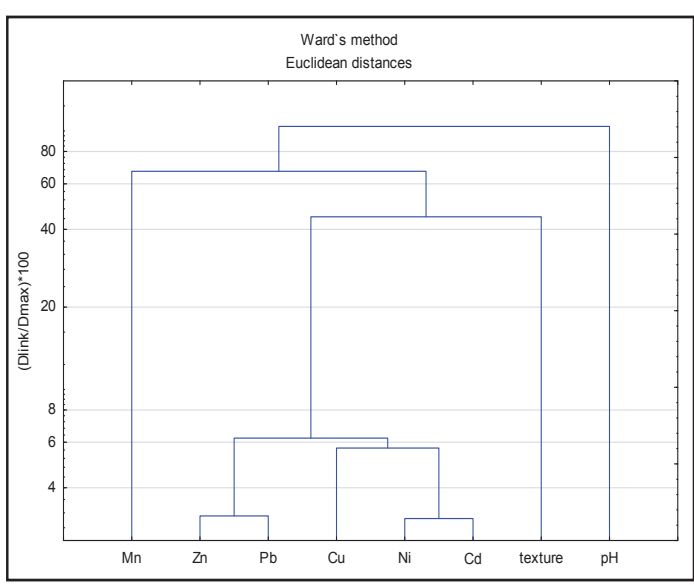

b)

Figure 10. Clusters' dendrograms of $\mathrm{pH}$, texture, metals $I_{\text {geo }}$ (a) and PI (b) 
According to the results of determination of texture the vast number of analyzed soil samples $(63 \%)$ is characterized as loam. The rest are sand (33\%) and clay soils (4\%). Data percentage distribution map of soil samples according to their $\mathrm{pH}$ is shown in Figure 12.
As a result of consistent mapping of pollution within the Pavlograd city area with six heavy metals were obtained corresponding distributions' maps (Fig.13).

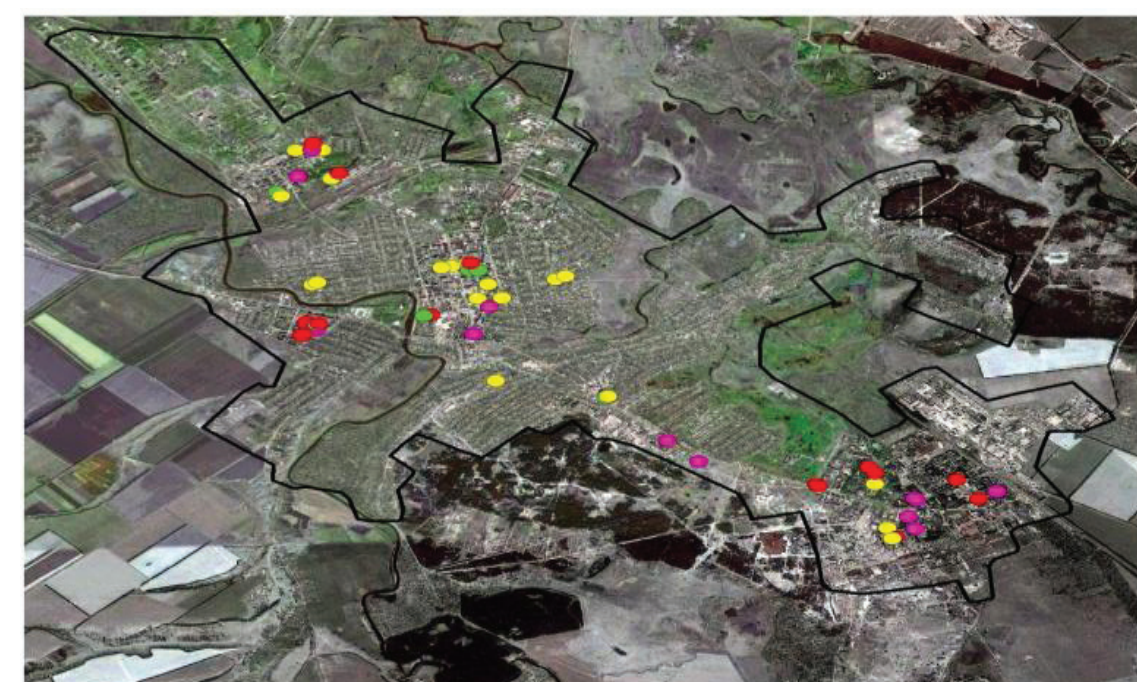

Figure 11. Locations of soil samples according to their texture composition

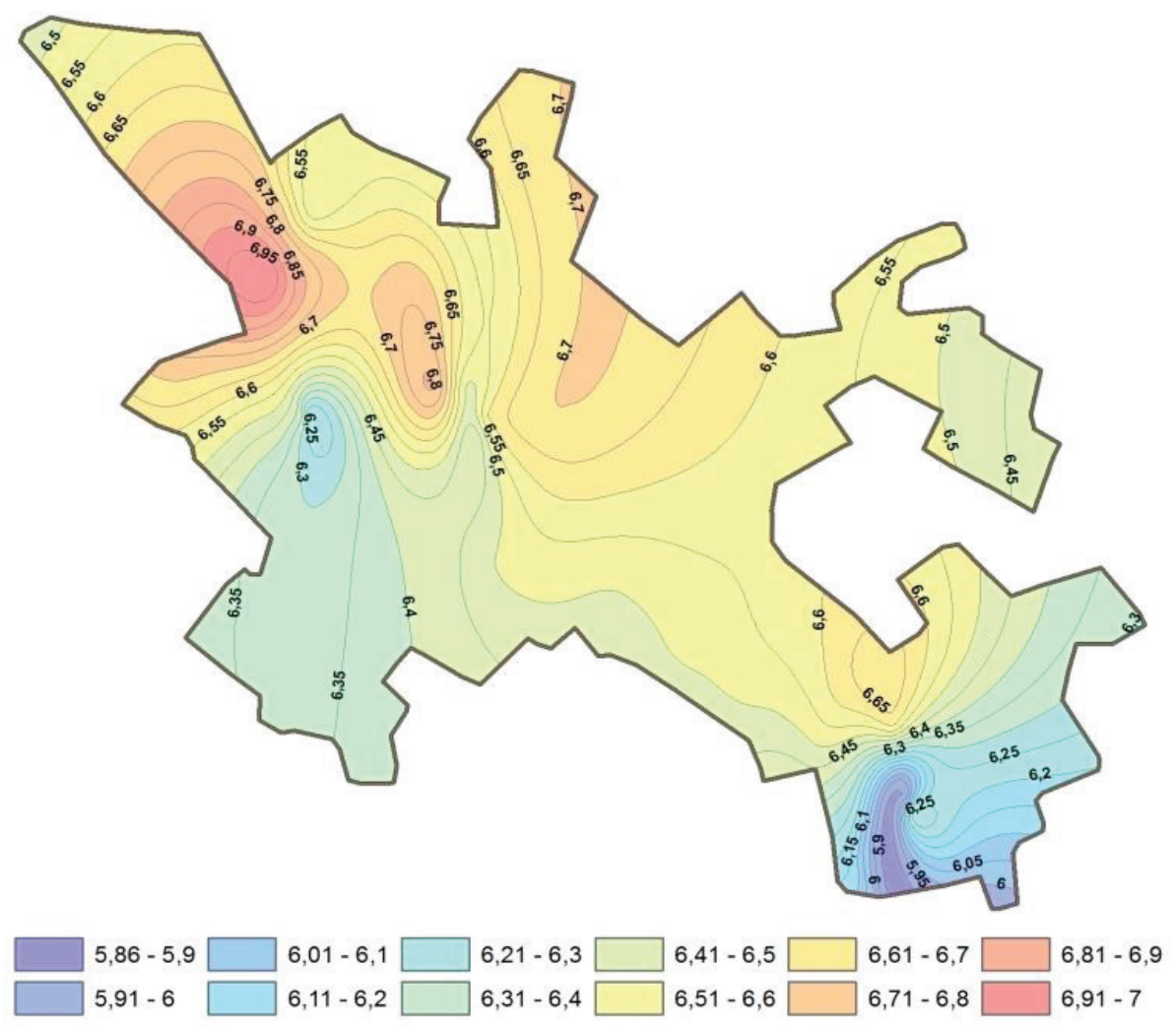

Figure 12. The map of the soil $\mathrm{pH}$ distribution 


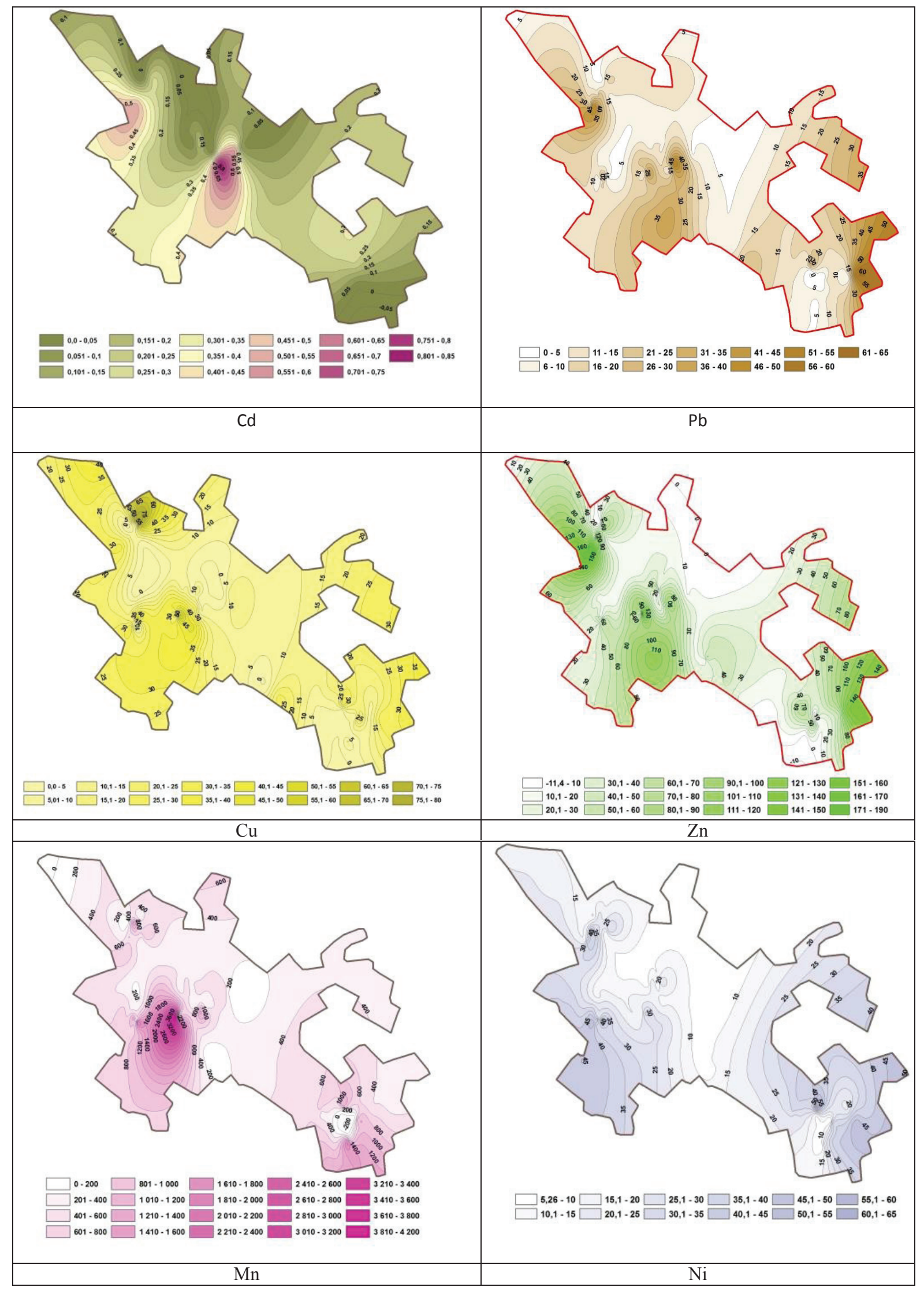

Figure 13. Heavy metals distributions in topsoil within the Pavlograd city area, $\mathrm{mg} / \mathrm{kg}$ 
The metal ions are injected into soil cover from main industrial facilities, coal-driven power plants, municipal and private waste refuses as well as form motor transport in Pavlograd city terrain. Sources of heavy metals emission in the South - Eastern part of city are caused by foundry and two machine building enterprises. The high density of soil contamination with $\mathrm{Cd}, \mathrm{Pb}, \mathrm{Mn}$ and $\mathrm{Ni}$ in the west of the city can be associated both with the activities of the Pavlograd chemical plant and the weathering process of coal mine heaps (Biliaiev \& Kharytonov, 2013; Kharytonov \& Kroik, 2011). Several case studies have demonstrated also that the combination of environmental mapping and multivariate geostatistical analysis can be an appropriate tool to characterize spatial distribution of heavy metals and to determine their sources (Luo et al., 2008; Li \& Feng, 2012; Yuan et al., 2013). Two Cd - hallows with range $0.4-05$ and $0.45-0.65$ were fixed in the western and south-west parts of city. High polluted with Mn hallow $(1210-3610 \mathrm{mg} / \mathrm{kg})$ was selected in the south-west parts of city as well. Similar character of spatial distribution was fixed for $\mathrm{Pb}, \mathrm{Zn}, \mathrm{Cu}$ and $\mathrm{Ni}$. In this case it is possible to see at least $4-5$ hallows in the east, south east, north and south west parts of studied city areas.

\section{Conclusion}

The vast number of analyzed soil samples in Pavlograd is characterized as loamy and have a weakly acidic $\mathrm{pH}$ at 6.3 and 6.8. The correlation matrix of metals data indicate positive correlation with correlation coefficient $r^{2}>0.5$ among texture - Ni (0.705) and $\mathrm{Pb}-\mathrm{Zn}(0.695)$ in Pavlograd city. In the case of $\mathrm{Cu}$ (2.73) and $\mathrm{Cd}$ (4.27), the geoaccumulation index indicated "moderately to strongly" and "strongly to extremely" polluted soils accordingly. Means of PI for heavy metals were between uncontaminated $(P \leq 1)$ and of moderate contaminated soils $(P \geq 1)$. The results of this study show that industrial enterprises activities lead to heavy metal contamination in the topsoil of the studied sites and close to the background values. Similar properties were confirmed by PCA and cluster analysis. The PCA and cluster analysis results indicate that $\mathrm{Cd}, \mathrm{Ni}, \mathrm{Pb}, \mathrm{Cu}, \mathrm{Zn}$ and $\mathrm{Mn}$ in topsoil were affected by the technogenic activity. The spatial distribution characteristics of $\mathrm{Cu}, \mathrm{Pb}, \mathrm{Cd}$ and $\mathrm{Zn}$ in the GIS geochemical maps are also similar. The metals come from anthropogenic sources, mainly produced with four industrial enterprises in Pavlograd city. Highlighted are some of the halos in Pavlograd of high density of total soil contamination with heavy metals. Mostly they are caused with impact of the industrial enterprises, which are localized in the South-East and in the West of the Pavlograd city. This study demonstrated that the combination of geostatistical and geospatial analysis are an appropriate tool to select emissions sources and to create GIS maps to characterize soil pollution with heavy metals in industrial city. It is necessary arrangements to predict of the development of ecologically dangerous state of environmental pollution within the area of industrial enterprises of the city.

\section{Acknowledgements}

The work has been funded by the Ukrainian Ministry of Education and Science.

\section{References}

Babiy A.P., Kharytonov M.M. \& Gritsan N.P., 2003, Connection between emissions and concentrations of atmospheric pollutants; part of the NATO Science Series, IV: Earth and environmental sciences, vol. 30: 11-19, [in:] D. Melas, D. Syrakov (eds.), Air Pollution Processes in Regional Scale. Kluwer Academic Publishers, printed in the Netherlands. https://link.springer.com/ chapter/10.1007/978-94-007-1071-9_2

Biasioli M., Barberis R. \& Ajmone-Marsan F., 2006, The influence of a large city on some soil properties and metals content. Science of the Total Environment 356: 154164. https://doi.org/10.1016/j.scitotenv.2005.04.033

Biliaiev M.M. \& Kharytonov M.M., 2013, The Numeric Forecast of Air Pollution Caused by a Blasting Accident in the Enterprise Responsible for Rocket Fuel Utilization in Ukraine, [in:] I. Barnes, K.J. Rudziński (eds.), Disposal of Dangerous Chemicals in Urban Areas and Mega Cities, NATO Science for Peace and Security Series C: Environmental Security, Springer, Dordrecgt, Netherlands: 313-327.

Biliaiev M.M., Rusakova T.I., Kolesnik V.Ye. \& Pavlichenko A.V., 2017, Determination of areas of atmospheric air pollution by sulfur oxide emissions from mining and metallurgical and energy generating enterprises. Naukovyi Visnyk Natsionalnoho Hirnychoho Universytetu 3: $100-106$.

Crutzen P.J., 2004, New directions: the growing urban heat and pollution "island" effect- impact on chemistry and climate. Atmospheric Environment 38: 3539-3540. doi:10.1016/j.atmosenv.2004.03.032

Dufour A., Amodei M., Ancellet G. \& Peuch V.-H., 2004, Observed and modelled "chemical weather" during ESCOMPTE. Atmos. Res. 74: 161-189. https://doi. org/10.1016/j.atmosres.2004.04.013

Fachinelli A., Sacchi E. \& Mallen L., 2001, Multivariate statistical and GIS, based approach to identify heavy metal source in soils. Environmental Pollution 114: 313324. https://doi.org/10.1016/S0269-7491(00)00243-8 
Fedoniuk R.H., Fedoniuk T.P., Zimaroieva A.A., Pazych V.M., Zubova O.V., 2020, Impact of air born technogenic pollution on agricultural soils depending on prevailing winds in Polissya region (NW Ukraine). Ecological Questions 31(1): 69-85. http://dx.doi.org/10.12775/ EQ.2020.007

Ghorani-Azam A., Riahi-Zanjani B. \& Mahdi BalaliMood M., 2016, Effects of air pollution on human health and practical measures for prevention in Iran. Journal of Research in Medical Sciences 21: 65 doi: 10.4103/1735-1995.189646

Guan Y., Shao C. \& Ju M., 2014, Heavy Metal Contamination Assessment and Partition for Industrial and Mining Gathering Areas. Int. J. Environ. Res. Public Health 11: 7286-7303. doi:10.3390/ijerph110707286

Joshi U.M. \& Balasubramanian R., 2010, Characteristics and environmental mobility of trace elements in urban runoff. Chemosphere 80: 310-318. https://doi. org/10.1016/j.chemosphere.2010.03.059

Johansson C., Norma M. \& Burman L., 2009, Road traffic emission factors for heavy metals. Atmospheric Environment 43: 4681-4688. https://doi.org/10.1016/j. atmosenv.2008.10.024

Karnaukh M. \& Lugovskoy S., 2008, Social, Medical and Environmental Consequences of Mining and Metallurgical Complex Activity in the Krivorozhsky Region and Decision Making, [in:] I. Barnes, M. Kharytonov (eds.), Simulation and Assessment of Chemical Processes in a Multiphase Environment, NATO Science for Peace and Security Series C: Environmental Security. Springer, Dordrecht, Netherlands: 377-384. doi: 10.1007/978-1-4020-8846-9 30

Khalilova H. \& Mammadov V., 2016, Assessing the Anthropogenic Impact on Heavy Metal Pollution of Soils and Sediments in Urban Areas of Azerbaijan's Oil Industrial Region. Pol. J. Environ. Stud. 25(1): 159-166. doi: 10.15244/pjoes/60723

Kharytonov M.M. \& Kroik A.A., 2011, Environmental Security of Solid Wastes in the Western Donbas Coal Mining Region, Ukraine, [in:] H. Alpas, Berkovich, I. Ermakova (eds.), Environmental Security and Ecoterrorism, NATO Science for Peace and Security Series C: Environmental Security, Chapter 10: 129-137. Springer, Dordrecht, The Netherlands. https://doi. org/10.1007/978-94-007-1235-5_10

Kolesnik V.Ye., Pavlichenko A.V., Borysovs'ka O. \& Buchavy Yu.V., 2018, Formation of Physic and Mechanical Composition of Dust Emission from the Ventilation Shaft of a Coal Mine as a Factor of Ecological Hazard. Solid State Phenomena 277: 178-187. https://doi. org/10.4028/www.scientific.net/SSP.277.178

Lee J., Chon H. \& Kim K., 1998, Migration and dispersion of trace elements in the rock-soil-plant system in areas underlain by black shale and slates. Journal of Geochemical Exploration 65: 61-78.

Li X.P. \& Feng L.N., 2012, Multivariate and geostatistical analyzes of metals in urban soil of Weinan industrial areas, Northwest of China. Atmospheric Environment 47: 58-65.

Luo W., Lu Y.L., Wang G., Shi Y.J., Wang T.Y. \& Giesy J.P., 2008, Distribution and avail-ability of arsenic in soils from the industrialized urban area of Beijing, China. Chemosphere 72: 797-802.

Maas S., Scheifler R., Benslama M., Crini N., Lucot E., Brahmia Z., Benyacoub S. \& Giraudoux P., 2010, Spatial distribution of heavy metal concentrations in urban, suburban and agricultural soils in a Mediterranean city of Algeria. Environmental Pollution 158: 2294-2301. doi:10.1016/j.envpol.2010.02.001

Manta D.S., Angelone M., Bellanca A., Neri R. \& Sprovieri M., 2002, Heavy metals in urban soils: a case study from the city of Palerma (Sicily), Italy. Science of Total Environment 300: 229-243. https://doi.org/10.1016/ S0048-9697(02)00273-5

Masaitis A. \& Miller G.C., 2014, Reduction of Conflicts in Mining Development using "Good Neighbor Agreements”, [in:] J.L. Drake, Y.Y. Kontar, G.S. Rife (eds.), The nature of communications, Chapter 5: 73-81. doi: 10.1007/978-3-319-01821-8_5

Müller G., 1969, Index of geoaccumulation in sediments of the Rhine River. Geojournal 2: 108-118.

Parrish D.D., Singh H.B., Molina L. \& Madronich S., 2011, Air quality progress in North American megacities: A review. Atmospheric Environment 45: 70157025. doi:10.1016/j.atmosenv.2011.09.039

Van Bohemen H.D. \& Janssen van de Laak W.H., 2003, The influence of road infrastructure and traffic on soil, water, and air quality. Environmental Management 31: 50-68.

Voitiuk Yu.Yu., Kuraieva I.V., Kroik A.A. \& Pavlychenko A.V., 2014, Ecological and geochemical assessment of the soil contamination levels in the areas of metallurgical enterprises operation. Naukovyi Visnyk Natsionalnoho Hirnychoho Universytetu 4: 1-7.

Yuan G.L., Sun T.H., Han P. \& Li J., 2013, Environmental geochemical mapping and multivariate geostatistical analysis of heavy metals in topsoils of a closed steel smelter: Capital Iron \& Steel Factory, Beijing, China. Journal of Geochemical Exploration 130: 15-21. http:// dx.doi.org/10.1016/j.gexplo.2013.02.010 